Journal of Social Sciences 1 (1): 1-8, 2005

ISSN 1549-3652

(C) Science Publications, 2005

\title{
HIV/AIDS Knowledge and Sexual Behavior Among Junior Secondary School Students in South Africa
}

\author{
${ }^{1}$ Karl Peltzer and ${ }^{2}$ Supa Promtussananon \\ ${ }^{1}$ Human Sciences Research Council and University of the North, South Africa \\ ${ }^{2}$ Department of Community Health, University of Venda for Science and Technology, S. Africa
}

\begin{abstract}
The aim of the study was to assess HIV/AIDS knowledge and sexual behaviour among junior Secondary School students in South Africa using a cross-sectional survey design. The sample consisted of 3150 students, with $44.1 \%$ were male and $55.9 \%$ female students. Their mean age was 15.75 yrs $(\mathrm{SD}=1.61)$ ranging from 13 to 24 years chosen from 150 schools in South Africa. Results indicate that $46 \%$ of the 16 year-old males and $20 \%$ of the 15.5 year-old females had already been sexually active. At first sex $63.8 \%$ of the male and $78.7 \%$ of the female students indicated that they had used a condom, but almost half (44\%) of those who had had sex before had not used a condom at last sex. One quarter of the students $(25.6 \%)$ indicated that they had had sex with someone much older than them (above $30 \mathrm{yrs}$ ), which was significantly higher among female $(31.2 \%)$ than male students $(22.9 \%)$ and significantly higher among non-urban $(28.4 \%)$ than urban $(17.2 \%)$ students. Twentyseven percent of the students reported that they had sex for the exchange of gifts. At an average age of 15.75 years the number of self-reported lifetime sex partners was for more than half of respondents, more than one partner. Further, the study found that knowledge of HIV/AIDS was poor in some areas and more satisfactory in other areas, but generally was not satisfactory enough to sustain adequate HIV/AIDS response in a context of high and widespread HIV/AIDS prevalence. Gender, tendency to use condoms and being sexually active had no significant relationship to levels of knowledge. HIV/AIDS knowledge was significantly higher in urban than in non-urban schools.
\end{abstract}

Key words: HIV/AIDS Knowledge, Sexual Behaviour, Junior Secondary School Students, South A frica

\section{INTRODUCTION}

In 2002, according to a national household HIV seroprevalence survey conducted in South Africa, the estimated national South African HIV prevalence rates for young people, per age group were: 15 to 19 year-olds $6 \%$ (4\% in males and $7 \%$ in females), 20 to 24 yearolds $13 \%$ ( $8 \%$ in males and $17 \%$ in females) and 25 to 29 year-olds $28 \%$ (22\% in males and $32 \%$ in females) and among African/Black youth (15-24 years) 10.2\%, Coloured youth $6.4 \%$, Indian youth $0.3 \%$ and Whites (15-49 years) $6.2 \%$ [1]. Given these levels of HIV prevalence it is important that the population be adequately appraised of the risks of HIV infection and that they have correct and useful knowledge to assist them to prevent HIV infection. Clearly knowledge is only part of what is needed in developing adequate HIV/AIDS response but it is certainly a commodity that cannot be done without. It is therefore of interest to understand the status of HIV/AIDS knowledge amongst affected populations.

[2] reviewed studies conducted on HIV/AIDS knowledge among South African "youth" aged 14-35 years and found that young people are very aware that AIDS is a disease that is sexually transmitted and fatal. They were less knowledgeable about HIV and how it is physically transmitted from one person to another, the asymptomatic carrier phase and methods for preventing HIV infection. The studies reviewed showed moderate to high levels of misconceptions about the risk of contracting HIV from casual contact with a person with HIV or AIDS, such as sharing clothes, toilet seats and eating utensils, coming into contact with saliva from coughing or spitting, dry kissing and from insect bites. They also illustrate that respondents show less knowledge when assessed with open-ended, rather than set-choice questions, suggesting low levels of spontaneous memory for AIDS information. Among mainly rural secondary school pupils in the Limpopo Province of South Africa in 1997, over $72 \%$ of the questions about AIDS were correctly answered, which at face value would suggest a fair degree of accurate information about AIDS; however, $18 \%$ were of the opinion that 'AIDS does not exist' and $19 \%$ believed that 'there is a cure for AIDS' [3]. Among junior rural secondary school pupils in the Limpopo Province $25.7 \%$ of the females responded to the question "Do condoms offer protection against HIV / AIDS ?" with "no" and $34.7 \%$ respondent to "Do condoms offer protection against sexually transmitted diseases?" with "no". 
[4] reviewed studies of sexual behaviour of school students in sub-Saharan Africa. Findings indicated a relatively low number of articles when one considers the scope of the problems related to adolescent sexual behaviour in the region; high prevalence rates of sexual intercourse; infrequent use of condoms and other contraceptives; and significant proportions of adolescents who have two or more lifetime sexual partners. In a South African study it was found among rural senior secondary school pupils that about half of the sexually active $(52.6 \%$ males and $40.5 \%$ females) reported never having used condoms [5]. [6] reported respondent complaints about intimidation, resistance and poor reception at the clinics when they requested condoms. [7] also did an explorative qualitative study to find out reasons for lack of condom use among high school students in Natal (South Africa). The subjects complained that condoms limited sexual pleasure indicated a lack of trust in the partner's faithfulness, challenged male ego and that condoms were perceived as associated with sexually transmitted diseases. They also complained that condom use was not sufficiently well understood and that condoms were not accessible or available when $\mathbf{e}$ quired.

We aimed to assess HIV/AIDS knowledge and sexual behaviour (including gender, age and rural/urban differences) among junior Secondary School students in South Africa.

\section{MATERIALS AND METHODS}

Design: The study is a cross-sectional survey as part of a post-intervention school survey on the distribution, use and impact of Soul City life skills materials in South Africa.

Sample and Procedure: In April 20026950 selfaddressed letters were sent to all secondary school principals in South Africa. A deadline of two months was given for the return of the survey questionnaire, only $473(6.8 \%)$ letters were returned. Thereafter a systematic random sample of 449 of 5977 secondary schools (excluding the 473 which had responded by letter and about 500 -mostly non-urban- schools, which did not have a telephone) were followed-up by telephonic interview. Therefore the total sample included 922 schools from which 522 indicated that they had eceived Soul City life skills materials and 490 had indicated that they actually covered some (50.4\%), half $(38.4 \%)$ and most parts $(11.2 \%)$ of the students work book. From this sample of 490 schools 150 were selected considering the learner's population by province to ensure a representative sample of urban and nonurban schools (which included schools servicing informal settlements) and some over sampling of schools with higher as compared to lower exposure to the Soul
City life skills students work book [8]. Table 1 indicates the schools and students by province.

Within each participating school one class was selected that had been exposed to life skills education using Soul City materials, which were mainly students in Grade 9 $(87.6 \%)$ and only a few in Grade $10(7 \%)$, Grade 8 $(4.7 \%)$ and $0.6 \%$ missing. In each class a range of 19 to 29 students (with a target of 20 for the administration of a questionnaire) were randomly selected.

The study was approved by the human ethics committee of the University of the North and all nine provincial education departments in South Africa. Consent was obtained from school principals, students in the selected classes as well as from their parents/guardians.

Questionnaires were administered in English in a classroom situation under the supervision of two trained postgraduate research assistants. All questions were read out to students in English and clarified during administration. Complete anonymity and confidentiality were as sured.

The total sample consisted of 3150 students, $44.1 \%$ were male and $55.9 \%$ female students and their mean age was 15.75 yrs $(\mathrm{SD}=1.61)$ ranging from 13 to 24 years. This included $1730(54.9 \%)$ from urban schools and $1420(45.1 \%)$ from non-urban schools.

The racial distribution was African/Black (2775, $88.1 \%)$, Coloured $(170,5.4 \%)$, White $(148,4.7 \%)$ and Asian $(57,1.8 \%)$. The ethnic distribution among African/Black was Zulu (768, 24.7\%), Northern Sotho (611, $19.4 \%)$, Xhosa $(512,16.3 \%)$, Tswana (331, 10.5\%), Southern Sotho $(318,10.1 \%)$, Tsonga (160, 5.1\%), Swazi $(127,4.0 \%)$, Ndebele $(65,2.1 \%)$, Venda (47, $1.5 \%)$, other $(3,0.1)$ and missing $(103,3.3 \%)$.

Measure: The questionnaire for the survey included:

* Sociodemographic information (Grade, age, sex, race, ethnic group);

* An 18-item Brief HIV Knowledge Questionnaire by [9] (Table 3, items 1-18). In addition, 7 bcally relevant items were included after focus groups with youth and expert interviews (Table 3, items 19-25). Response options were true, false and do not know. Correct answers were coded as " 1 ", "false" and "I do not know" as " 0 ", which were summed up to give a composite knowledge score. Cronbach alpha for this scale in this sample was .76 .

* 8 items on sexual behaviour (items 1-3 and 6 were taken from [10] and items 4 and 5 from local cultural knowledge generated from focus groups with youth and expert interviews.

Experts included HIV educators, traditional healers and health professionals and focus group members included Junior Secondary School students. They were asked to comment on cultural beliefs on the nature and transmission of HIV. 


\section{RESULTS}

Sexual Behavior: At a mean age of 15.75 yrs $(\mathrm{SD}=1.61$ ) (boys: 16.0 yrs, $\mathrm{SD}=1.6$; girls: $15.5 \mathrm{yrs}$, $\mathrm{SD}=1.5)$ almost one-third $(31.5 \%)$ of the total sample indicated that they had had sexual intercourse. There were significantly more male $(46.3 \%)$ than female $(19.8 \%)$ students who had had sex before $\left(X^{2}=9.57\right.$, $\mathrm{p}<.001)$ and significantly more non-urban $(35.7 \%)$ than urban $(27.7 \%)$ students $\left(X^{2}=22.14, \mathrm{p}<.001\right)$. One needs, however, to consider that non-urban students (15.93 yrs, $\mathrm{SD}=1.70)$ were significantly older than urban students (15.54 yrs, $\mathrm{SD}=1.47)(\mathrm{t}=-6.57, \mathrm{p}<.001)$. Comparing urban and non-urban students below 17 years, $20.8 \%$ of the urban and $24.8 \%$ of the non-urban students had had sexual intercourse before $\left(X^{2}=4.82\right.$, $\mathrm{p}<.05)$ and comparing below 16 year-old students, $17.1 \%$ of the urban and $18.7 \%$ of the non-urban students had sexual intercourse $\left(X^{2}=.69\right.$, ns). Age was inversely related to having had sexual intercourse $(r=-$ $.33, \mathrm{p}<.001)$. Table 2 indicates sexual behaviour by gender and location.

Among the sexually active group the mean age of first sexual intercourse was 14.6 years $(\mathrm{SD}=2.9)$. This was significantly lower among boys $(14.0 \mathrm{yrs}, \mathrm{SD}=2.8)$ than among girls $(15.4$ yrs, $\mathrm{SD}=2.4)(\mathrm{t}=5.88, \mathrm{p}<.001)(\mathrm{me}-$ dian 14.5 and 15.5 years, respectively) and significantly lower among students from urban schools $(\mathrm{M}=14.1 \mathrm{yrs}, \mathrm{SD}=3.0$ ) (median 14 and 15 years, espectively) than students from non-urban schools $(\mathrm{M}=14.8 \mathrm{yrs}, \mathrm{SD}=2.5)(\mathrm{F}=10.60, \mathrm{p}<.001)$. None of the students report having had sexual intercourse at the age of 13 years or below. Reported ages of sexual debut were $9.7 \%$ at the age of 14 years, $16.4 \%$ at 15 years, $23.6 \%$ at 16 years, $22.1 \%$ at 17 years and $26.7 \%$ at 18 years and above.

At first sex $63.8 \%$ of the male and $78.7 \%$ of the female students indicated that they had used a condom. Condom use at last sex was $56 \%$ and significantly higher among female than male students.

One quarter of the students $(25.6 \%)$ indicated that they had had sex with someone much older than them (above $30 \mathrm{yrs}$ ), which was significantly higher among female $(31.2 \%)$ than male students $(22.9 \%)$ and significantly higher among non-urban $(28.4 \%)$ than urban $(17.2 \%)$ students. Twenty-seven percent of the students reported that they had had sex for the exchange of gifts. At an average age of 15.75 years the number of selfreported lifetime sex partners was for more than half of those who had had sex before more than one partner. Male students had significantly more sex partners during their lifetime than female students.

HIV/AIDS Knowledge: The overall mean HIV knowledge score was $12.31(\mathrm{SD}=3.76)$, with a range of 0 to
25 scores. Age was inversely associated with HIV/AIDS knowledge $(\mathrm{r}=-07, \mathrm{p}<.001)$. There were no significant gender differences $(\mathrm{t}=1.49)$ and also no difference between those who had had sexual intercourse or not $(\mathrm{F}=1.91$, ns $)$. Students from urban schools $(\mathrm{M}=12.95, \mathrm{SD}=3.9)$ had significantly better HIV/AIDS knowledge than students from non-urban schools $(\mathrm{M}=11.78, \mathrm{SD}=3.5)(\mathrm{F}=78.06, \mathrm{p}<.001)$. White students had the highest HIV/AIDS knowledge $(\mathrm{M}=16.5$, $\mathrm{SD}=4.4)$, followed by Asians $(\mathrm{M}=15.0, \mathrm{SD}=3.6)$, Coloureds $(M=13.3, S D=4.1)$ and African/Blacks $(M=12.1$, $\mathrm{SD}=3.6)$. Amongst the sexually active, there were no differences between HIV/AIDS knowledge and condom use at last sex $(F=.00$, ns $)$, number of lifetime sexual partners $(\mathrm{F}=.88, \mathrm{~ns})$ and history of having had sex in exchange for gifts $(\mathrm{F}=2.72)$. Having had sex with someone much older was inversely related with HIV/AIDS knowledge ( $F=11.22, p<.001)$. Life skills exposure was positively associated with the HIV/AIDS knowledge score $(r=.04, \mathrm{p}<.05)$. Table 3 indicates students' knowledge about HIV/AIDS.

Table 1: Sample of Students by Province

\begin{tabular}{lccc}
\hline & \multicolumn{2}{c}{ No. of Schools } & \multicolumn{2}{c}{ No. of Students } \\
& $f$ & $f$ & $\%$ \\
\hline Eastern Cape & 22 & 428 & 13.6 \\
Free State & 10 & 212 & 6.7 \\
Gauteng & 20 & 322 & 10.2 \\
Limpopo & 25 & 601 & 19.1 \\
Kwa-Zulu Natal & 34 & 731 & 23.2 \\
Mpumalanga & 12 & 265 & 8.4 \\
Nothern Cape & 4 & 80 & 2.5 \\
North West & 11 & 259 & 8.2 \\
Western Cape & 12 & 242 & 7.7 \\
\hline Total & 150 & 3150 & 100 \\
\hline
\end{tabular}

Looking at particular HIV/AIDS knowledge $70 \%$ and more of the students had the correct knowledge about HIV transmission myths (sitting next to a person with HIV, sharing a glass of water with someone who has HIV or being in a swimming pool with a person with HIV) and curability (by having sex with a disabled or old woman or virgin). Twenty five percent or less knew about an HIV infection window period, that a natural skin condom does not work better against HIV than a latex condom and HIV transmission (that a person can get HIV from oral sex and that not all pregnant women infected with HIV will have babies born with AIDS). Table 4 indicates learner's knowledge about HIV by gender and location. 
Table 2: Sexual Behavior by Gender and Location

\begin{tabular}{|c|c|c|c|c|c|c|c|c|}
\hline Item & Male & Female & Total & Total & $X^{2}$ & Urban & Non-urban & $X^{2}$ \\
\hline & $\%$ & $\%$ & $f$ & $\%$ & & $f$ & $\%$ & \\
\hline $\begin{array}{l}\text { 1.Have you ever had } \\
\text { sexual intercourse? }\end{array}$ & 46.3 & 19.8 & 914 & 31.5 & $220.66^{* *}$ & $* 27.7$ & 35.7 & $22.14 * * *$ \\
\hline $\begin{array}{l}\text { 2.Did you use a condom at the } \\
\text { first sexual intercourse? }\end{array}$ & 63.8 & 78.7 & 224 & 68.7 & $8.15^{*}$ & 58.3 & 63.4 & 2.77 \\
\hline $\begin{array}{l}\text { 3.The last time you had sexual } \\
\text { intercourse, did you or your } \\
\text { partner use a condom? } \\
\text { 4.Did you ever have sex with }\end{array}$ & 50.8 & 66.8 & 385 & 56.0 & $15.87^{* * *}$ & * 55.2 & 55.7 & .03 \\
\hline $\begin{array}{l}\text { someone much older than you } \\
\text { (above } 30 \text { yrs)? } \\
\text { 5.Have you ever had sex }\end{array}$ & 22.9 & 31.2 & 186 & 25.6 & $5.71^{*}$ & 17.2 & 28.4 & $20.26 * * *$ \\
\hline $\begin{array}{l}\text { for the exchange of gifts? } \\
\text { 6.During your life, } \\
\text { with how many people } \\
\text { have you had sex }\end{array}$ & 26.4 & 28.3 & 195 & 27.0 & .30 & 25.5 & 27.7 & .71 \\
\hline 1 person & 33.0 & 68.1 & 286 & 44.1 & $75.89 * * *$ & * 47.5 & 49.9 & 1.18 \\
\hline 2-3 people & 33.3 & 20.6 & 190 & 29.3 & & 28.6 & 26.9 & \\
\hline 4-5 people & 15.7 & 2.5 & 75 & 11.6 & & 9.2 & 10.1 & \\
\hline 6 or more people & 18.0 & 8.8 & 98 & 15.1 & & 14.7 & 13.0 & \\
\hline
\end{tabular}

Responses to question 1 are based on all participants and responses to questions 2 to 6 are based only on those who had had sexual intercourse.

$* * * \mathrm{p}<.001, * * \mathrm{p}<.01, * \mathrm{p}<.05$

Male students believed more than female students that "People who have been infected with HIV quickly show serious signs of being infected" and female students believed more than male students that "Pulling out the penis before a man climaxes/cums (ejaculates) keeps a woman from getting HIV during sex", "A person will NOT get HIV if she or he is taking antibiotics" and "One can HIV through witchcraft".

On 18 of the 25 knowledge items non-urban students indicated significantly less correct knowledge than urban students and on one item "One can get HIV through witchcraft" surprisingly urban students had significantly less correct knowledge than non-urban students.

\section{DISCUSSION}

HIV/AIDS Knowledge: The study found that knowledge of HIV/AIDS was poor in some areas and more satisfactory in other areas, but generally was not satisfactory. Gender, tendency to use condoms and being sexually active had no significant relationship to levels of knowledge. HIV/AIDS knowledge was significantly higher in urban than in non-urban schools.

Younger and urban students as well as those who had not had sex with someone much older than them had significantly more HIV/AIDS knowledge than older and non-urban students and those who had sex with people 30 years older than them.

Comparing HIV knowledge with other studies is difficult since mostly other items have been used and most studies involved older age groups. In one study with a similar age group among Kenyan secondary school students $(M=16.3$ years) $21.9 \%$ had misconceptions of transmission of HIV through mosquitoes as compared to $27.1 \%$ in this study $(\mathrm{M}=15.6$ years) [11]. In a South African national youth survey (12-17 years) $7 \%$ agreed and $18 \%$ responded "Don't know" to the statement "Having sex with a virgin cures you of AIDS" [12]. In an older age group (15-24 years) of a national South African household sample slightly better knowledge was found than in this study, namely for "HIV can be transmitted by kissing" 75.9\%, "AIDS can be caused by witchcraft" $85.3 \%$ and "AIDS can be cured by sex with a virgin" $89.2 \%$ correct knowledge as compared to $58.8,53.9$ and $69.6 \%$, respectively, in this sample [1]. AIDS "myth" (beliefs that HIV can be spread through mosquito bites, kissing, sharing eating utensils and casual contact or cured by having sex with a virgin, disabled or old woman) were found to be held by a minority $(10-25 \%)$ of students in this study, which seems conform to other studies in South Africa [2]. Although there was $50-60 \%$ understanding of the asymptomatic or healthy carrier state, some students seem to assume that there is some way to tell who has HIV/AIDS, $18 \%$ believed $(21 \%$ did not know) that a healthy looking person can be infected with HIV and $25 \%$ agreed to (27\% did not know) the statement that people who have been infected with HIV quickly show serious signs of being infected. Further research is needed to investigate factors that give rise to the myth of getting cured from HIV by having sex with a virgin, disabled or old women.

On eight HIV/AIDS knowledge items more than $35 \%$ of the students answered with "I don't know", ranging from " a natural skin condom works better against HIV than does a latex condom" (59.7\%) to "getting HIV 
Journal of Social Sciences 1 (1): 1-8, 2005

ISSN 1549-3652

(C) Science Publications, 2005

Table 3: Learner's Knowledge about HIV in Correct Answers in Percent and Descending Order of Frequency (bold Indicates Correct Answer)

\begin{tabular}{|c|c|c|c|}
\hline Questions & $\begin{array}{c}\text { True } \\
\%\end{array}$ & $\begin{array}{c}\text { False } \\
\%\end{array}$ & $\begin{array}{c}\text { Do not know } \\
\%\end{array}$ \\
\hline $\begin{array}{l}\text { 24. One can get HIV by sitting next } \\
\text { to a person with HIV. } \\
\text { 2.A person can get HIV by sharing }\end{array}$ & 6.3 & 87.5 & 6.2 \\
\hline $\begin{array}{l}\text { a glass of water with someone who has HIV. } \\
\text { 16.A person can get HIV by sitting in a hot tub }\end{array}$ & 13.1 & 77.2 & 9.7 \\
\hline $\begin{array}{l}\text { or a swimming pool with a person who has HIV. } \\
\text { 23.Having sex with a disabled or old }\end{array}$ & 9.8 & 76.3 & 13.9 \\
\hline woman can cure HIV/AIDS. & 9.1 & 72.7 & 18.2 \\
\hline 22.Having sex with a virgin can cure HIV/AIDS. & 13.1 & 69.6 & 17.3 \\
\hline $\begin{array}{l}\text { 14. Having sex with more than one partner can increase } \\
\text { a person's chance of being infected with HIV. } \\
\text { 11. There is a female condom that can help }\end{array}$ & 64.6 & 17.4 & 18.0 \\
\hline $\begin{array}{l}\text { decrease a woman's chance of getting HIV. } \\
\text { 19.A healthy looking person can be infected }\end{array}$ & 63.1 & 13.4 & 23.6 \\
\hline with HIV, the virus that causes AIDS. & 61.0 & 17.9 & 21.0 \\
\hline $\begin{array}{l}\text { 5. Showering, or washing one's genitals/private parts, } \\
\text { after sex keeps a person from getting HIV. } \\
\text { 9.People are likely to get HIV by deep kis sing, putting their }\end{array}$ & 12.5 & 58.8 & 28.7 \\
\hline $\begin{array}{l}\text { Tongue in their partner's mouth, if their partner has HIV. } \\
\text { 18.Using Vaseline or baby oil with condoms lowers }\end{array}$ & 23.0 & 58.7 & 18.3 \\
\hline the chance of getting HIV. & 9.9 & 56.3 & 33.9 \\
\hline 20.You can get HIV through an open cut or wound. & 54.0 & 15.6 & 30.4 \\
\hline 21.One can get HIV through witchcraft. & 10.4 & 53.9 & 35.7 \\
\hline 25.HIV can be spread by mosquitoes. & 27.1 & 48.9 & 24.0 \\
\hline $\begin{array}{l}\text { 7. People who have been infected with HIV quickly show } \\
\text { serious signs of being infected. }\end{array}$ & 24.9 & 48.5 & 26.7 \\
\hline 1.Coughing and sneezing DO NOT spread HIV. & 46.4 & 27.0 & 26.6 \\
\hline 8. There is a vaccine that can stop adults from getting HIV. & 18.7 & 45.2 & 36.1 \\
\hline 10.A woman cannot get HIV if she has sex during her period. & 19.4 & 42.8 & 37.7 \\
\hline 13.A person will NOT get HIV if she or he is taking antibiotics. & 20.2 & 37.8 & 42.0 \\
\hline $\begin{array}{l}\text { 4.A woman can get HIV if she has anal sex with a man. } \\
\text { 3.Pulling out the penis before a man climaxes/cums (ejaculates) }\end{array}$ & 31.2 & 24.8 & 44.0 \\
\hline $\begin{array}{l}\text { keeps a woman from getting HIV during sex. } \\
\text { 15.Taking a test for HIV one week after having sex will tell a }\end{array}$ & 20.2 & 30.3 & 49.5 \\
\hline $\begin{array}{l}\text { person if she or he has HIV. } \\
\text { 12.A natural skin condom works better against }\end{array}$ & 44.4 & 25.3 & 30.3 \\
\hline HIV than does a latex condom. & 16.3 & 24.0 & 59.7 \\
\hline $\begin{array}{l}\text { 17.A person can get } \mathrm{HIV} \text { from oral sex } \\
\text { (mouth-to-penis or mouth-to- vagina). } \\
\text { 6.All pregnant women infected with HIV }\end{array}$ & 24.0 & 38.3 & 37.7 \\
\hline will have babies born with AIDS. & 63.7 & 22.0 & 14.4 \\
\hline
\end{tabular}


Table 4: Learner's Knowledge about HIV in Correct Answers and in Percent by Gender and Location

\begin{tabular}{|c|c|c|c|c|c|c|}
\hline Questions & Male & Female & $X^{2}$ & Urban & Non-urban & $X^{2}$ \\
\hline 1.Coughing and sneezing DO NOT spread HIV. & 43.3 & 48.8 & $8.53^{* *}$ & 55.5 & 38.9 & $83.85 * * *$ \\
\hline $\begin{array}{l}\text { 2.A person can get HIV by sharing a glass of water } \\
\text { with someone who has HIV. } \\
\text { 3.Pulling out the penis before a man climaxes/cums } \\
\text { (ejaculates) keeps a woman from getting }\end{array}$ & 77.7 & 7.9 & .07 & 82.7 & 72.7 & $43.71 * * *$ \\
\hline $\begin{array}{l}\text { HIV during sex. } \\
4 . \text { A woman can get HIV if she has }\end{array}$ & 34.0 & 26.5 & $18.60^{* * *}$ & $* 33.0$ & 28.0 & $8.85^{* *}$ \\
\hline anal sex with a man. & 32.5 & 29.5 & 2.98 & 33.5 & 29.3 & $5.93^{*}$ \\
\hline $\begin{array}{l}\text { 5.Showering, or washing one's genitals/private parts, } \\
\text { after sex keeps a person from getting HIV. } \\
\text { 6.All pregnant women infected with HIV }\end{array}$ & 61.3 & 57.2 & $4.67^{*}$ & 61.2 & 56.8 & $6.20^{*}$ \\
\hline $\begin{array}{l}\text { will have babies born with AIDS. } \\
\text { 7.People who have been infected with HIV quickly }\end{array}$ & 21.1 & 22.6 & .98 & 24.4 & 20.0 & $8.47 * *$ \\
\hline $\begin{array}{l}\text { show serious signs of being infected. } \\
\text { 8.There is a vaccine that can stop }\end{array}$ & 44.2 & 51.9 & $16.12 * * *$ & $* 53.1$ & 44.6 & $21.41 * * *$ \\
\hline adults from getting HIV. & 60.8 & 61.4 & .11 & 66.4 & 56.6 & $30.65^{* * *}$ \\
\hline $\begin{array}{l}\text { 9.People are likely to get HIV by deep kissing, } \\
\text { putting their tongue in their partner's mouth, } \\
\text { if their partner has HIV. }\end{array}$ & 46.0 & 44.6 & .59 & 43.4 & 46.7 & 3.39 \\
\hline $\begin{array}{l}\text { 10.A wo man cannot get HIV if she has sex } \\
\text { during her period. } \\
\text { 11. There is a female condom that can help }\end{array}$ & 59.3 & 58.8 & .06 & 63.5 & 54.9 & $23.59 * * *$ \\
\hline $\begin{array}{l}\text { decrease a woman's chance of getting HIV. } \\
\text { 12.A natural skin condom works better against }\end{array}$ & 43.5 & 43.9 & .05 & 49.2 & 37.6 & $41.54 * * *$ \\
\hline HIV than does a latex condom. & 66.1 & 62.3 & $4.35^{*}$ & 62.2 & 63.7 & .73 \\
\hline $\begin{array}{l}\text { 13.A person will NOT get HIV if she or } \\
\text { he is taking antibiotics. }\end{array}$ & 29.1 & 20.1 & $30.65 * * *$ & $* 24.0$ & 24.0 & .00 \\
\hline $\begin{array}{l}\text { 14.Having sex with more than one partner } \\
\text { can increase a person's chance of being } \\
\text { infected with HIV. }\end{array}$ & 38.0 & 37.9 & .00 & 41.1 & 35.0 & $11.87 * * *$ \\
\hline $\begin{array}{l}\text { 15. Taking a test for HIV one week after having sex } \\
\text { will tell a person if she or he has HIV. } \\
\text { 16.A person can get HIV by sitting in a hot tub or a }\end{array}$ & 66.2 & 63.1 & 2.81 & 68.8 & 61.1 & $19.84 * * *$ \\
\hline $\begin{array}{l}\text { swimming pool with a person who has HIV. } \\
\text { 17.A person can get HIV from oral sex }\end{array}$ & 25.8 & 24.0 & 1.23 & 24.2 & 26.2 & 1.57 \\
\hline $\begin{array}{l}\text { (mouth-to-penis or mouth-to- vagina). } \\
\text { 18.Using Vaseline or baby oil with condoms }\end{array}$ & 75.2 & 78.2 & 3.66 & 80.2 & 73.1 & $21.36 * * *$ \\
\hline $\begin{array}{l}\text { lowers the chance of getting HIV. } \\
\text { 19.A healthy looking person can be infected with }\end{array}$ & 26.7 & 21.6 & $9.86^{* *}$ & 23.6 & 24.3 & .17 \\
\hline HIV, the virus that causes AIDS. & 59.2 & 54.8 & $5.44 *$ & 56.3 & 56.2 & .00 \\
\hline 20. You can get HIV through an open cut or wound. & 54.2 & 54.4 & .01 & 56.7 & 51.7 & $7.48 * *$ \\
\hline 21.One can get HIV through witchcraft. & 56.9 & 51.4 & $8.25 * *$ & 49.0 & 57.8 & $23.64 * * *$ \\
\hline 22.Having sex with a virgin can cure HIV/AIDS. & 68.5 & 71.6 & 3.24 & 77.0 & 63.5 & $65.71 * * *$ \\
\hline $\begin{array}{l}\text { 23. Having sex with a disabled or old woman } \\
\text { can cure HIV/AIDS. } \\
\text { 24. One can get HIV by sitting next }\end{array}$ & 70.7 & 73.8 & 3.35 & 76.4 & 69.6 & $17.85 * * *$ \\
\hline to a person with HIV. & 87.1 & 89.3 & 3.12 & 91.6 & 84.1 & $39.64 * * *$ \\
\hline 25.HIV can be spread by mosquitoes. & 47.4 & 51.4 & 4.39 & 52.1 & 46.2 & $10.27 * * *$ \\
\hline
\end{tabular}
$* * * \mathrm{p}<.001, * * \mathrm{p}<.01, * \mathrm{p}<.05$ 
(C) Science Publications, 2005

through witchcraft" (35.7\%). Some of the "don't know" responses may be explained by lack of information about HIV/AIDS such as the "natural skin condom". Other "don't know" responses of the students may reflect ambivalent sources of information and attitudes such as "getting HIV through witchcraft" or "a person can get HIV from oral sex".

It is further interesting that -with some exceptions- as the frequency of correct answers are reducing on the different items of the HIV/AIDS knowledge scale they are not so much accompanied by an increase in incorrect answers but by an increase in "don't know" answers. Implications for HIV education could be that students with "don't know" items are potentially easier educable than students with incorrect answers such as "There is a vaccine that can stop adults from getting HIV".

Incorrect responses may be based on cultural and other beliefs that may need special educational efforts to change. Items with high incorrect answers included "All pregnant women infected with HIV will have babies born with AIDS"(63.7\%), "Taking a test for HIV one week after having sex will tell a person if she or he has HIV" $(44.4 \%)$ or "People are likely to get HIV by deep kissing if their partner has HIV" $(23.0 \%)$. This lack of detailed knowledge or not knowing the exceptions of the rule may be attributed to not getting the whole information from the media or other sources of HIV information. The item on "People are likely to get HIV by deep kissing if their partner has HIV" is false because the statement emphasizes on the likelihood of transmission, while there are exceptions of transmission in case of a mouth ulcer. On various HIV knowledge items the study showed gender and rural-urban diffe rences, which need to be considered in HIV prevention intervention programmes. For example, more male than female students believed that "People who have been infected with HIV quickly show serious signs of being infected". The quickly showing signs of HIV disease may be related to the understanding of males about other sexually transmitted disease that show more quickly signs in males than in females.

Further, more urban than non-urban students believed that "One can get HIV through witchcraft". This finding is contrary to what [13] noted that witchcraft is believed to be the causal agent in HIV transmission and AIDS in many African countries, especially among rural poor or least-educated people. However, adolescents undergoing socio-cultural change in urban contexts may increasingly recur to witchcraft beliefs [14]. AIDS education has to take into account these beliefs in personal and ultimate causes of HIV and has to stress the immediate cause of a "germ" which is sexually transmitted and discourage the belief that HIV is attributed to external or supernatural powers that go beyond the individual's responsibility or accountability of one's own behaviour.

This study found age inversely related with HIV/AIDS knowledge, which can be explained as a result of the sample selection within a single Grade. Those who are older in this Grade would be educationally disadvantaged (due to lower school performance) over the younger ones. Other studies such as in a random sample of secondary school students in the Limpopo Province (aged 17-24) found no significant effect for age [3].
Further, students from urban schools seemed to have more knowledge about HIV/AIDS than students from non-urban schools, which were also found in another South African study by Goliath in [2]. In this study White and Asian students seemed to have more knowledge about HIV/AIDS than Coloured and African/Black students. [2] reviewed that some studies in South Africa show that English speakers were better informed than other language groups.

Lower levels of HIV/AIDS knowledge among African/Black students from non-urban schools needs to be addressed. Further, this study found a relatively large incorrect and "do not know" answers on HIV/AIDS myth, which need to be addressed through clear education messaging and social-cultural influence change. Knowledge of HIV transmission was not clearly linked with sexual activities of respondents. For instance, among the sexually active there were no differences between HIV/AIDS knowledge and condom use at last sex and number of lifetime sexual partners.

Sexual Behaviour: The mean age at onset of sexual activity was in this sexually active sample among males 14.0 and among females 15.4 years (median 14.5 and 15.5 , respectively); $31.5 \%$ were sexually active at the age of 15.75 years. [15] suggest that at least $50 \%$ of young people in South Africa are sexually active by age 16. In this study $46 \%$ of the 16 year-old males and $20 \%$ of the 15.5 year-old females had already been sexually active and in total $31.5 \%$, which is almost the same (31\% as found in the South African national youth survey (ages 12-17 years) [12]. In the Nelson Mandela/HSRC Study of HIV/AIDS [1] relatively low levels of sexual activity (25\%) amongst 15 to 17 year-old youth were found.

According to [4] the age of 13 to 14 years is an important transition point for interventions that aim to delay the onset of sexual activity among adolescents. This study found that the onset of sexual activity was slightly lower among students from urban than from non-urban schools, while [16] found in a study among youth from different sites in South Africa that rural sites had earlier starting ages for sexual intercourse. A reason for this may be that in the latter study non-schooling youth was included who may account for the younger age of sexual debut.

This present study found that significantly more nonurban $(35.7 \%)$ than urban $(27.7 \%)$ students had had sexual intercourse, which is similar to the findings from the South African national youth survey, namely 34 and $26 \%$, respectively [12].

At first sex one-third of the students in this study, especially males, indicated that they had not used a condom, almost half (44\%) had not used a condom at last sex. Among older age groups in South Africa it was found that amongst 15 to 24 year-olds $57.1 \%$ of the males and $46.1 \%$ of the females indicated that they had used a condom during the last sexual intercourse [1] and among South African youth from different sites (Mean age 20.4 years) $52 \%$ indicated condom use at last sex [16]. 
About one quarter of the students in this study, especially among females and non-urban students indicated that they had had sex with someone much older than them (above $30 \mathrm{yrs}$ ) and/or had had sex for the exchange of gifts and the number of self-reported lifetime sex partners was for more than half more than one partner and for $33.7 \%$ of the boys and $11.3 \%$ of the girls 4 or more lifetime sexual partners. In the South African national youth survey (12-17 years) $20 \%$ of the boys had given and $16 \%$ of the girls had received money, drinks, food or other gifts for sex (9). [15] found in their review on South African youth that the majority of school students who had ever experienced sexual intercourse reported at the most one partner in the previous year, with a persistent minority of between $1 \%$ and $5 \%$ of females and 10-25\% of males having more than four partners per year. However, in this study as well as in other African samples a large proportion of adolescents reported two or more sexual partners indicating the need for further studies addressing the sexual behaviors of adolescents still favoring on-going HIV transmission $[4,17]$.

Limitations: Due to the sampling bias towards exp osure to life skills education and schools which had a telephone, the sample is not representative to the whole country and one should not generalize findings.

\section{CONCLUSION}

The study found that knowledge of HIV/AIDS was poor in some areas and more satisfactory in other areas, but generally was not satisfactory enough to sustain adequate HIV/AIDS response in a context of high and widespread HIV/AIDS prevalence. The lower levels of knowledge in younger youth, gender, racial and urbannon-urban differences as in this study should be addressed by AIDS education efforts. Younger samples of students or youth like the current one should be investigated in order to address their specific HIV prevention intervention needs. Further, more uniform HIV knowledge questionnaire items should be used and standardized so as to compare findings from different study populations.

\section{ACKNOWLEDGEMENTS}

This study forms part of an evaluation of Soul City life skills materials commissioned by Soul City. The contribution of Dr S Goldstein and Dr L Cherian towards the design of the evaluation and the work of the research assistants M. Bopape, G. Phaswana, E. Sethosa, S. Raphala, C. Ledwaba, M. Phoshoko, T. Rambau and N Rasodi are hereby acknowledged. Furthermore, we are grateful for the generous financial support by Soul City, Johannesburg.

The anonymous reviewers are thanked for their useful comments.

\section{REFERENCES}

1. Nelson Mandela/HSRC Study of HIV/AIDS, 2002. South African national HIV prevalence, behavioural risks and mass media household sur- vey 2002. Cape Town: Human Sciences Research Council, South A frica.

2. Eaton, L. and A.J. Flisher, 2000. HIV/AIDS knowledge among South African youth. Southern African J. Child and Adolescent Mental Health, 12: $97-124$.

3. Peltzer, K., 2001. Factors affecting behaviors that address HIV risk among senior secondary school pupils in South Africa. Psychological Reports, 89: 51-56.

4. Kaaya, S.F., A.J. Flisher, J.K. Mbwambo, H. Schaalma, L.E. Aaro, and K.I.A. Klepp, 2002. Review of studies of sexual behaviour of students in sub-Saharan Africa. Scandinavian J. Public Health, 30: 148-160.

5. Peltzer, K., 2000. Factors affecting condom use among junior Secondary School pupils in South Africa. Health SA Gesondheid, 5: 37-44.

6. Abdool-Karim, Q., E. Preston-Whyte, and S.S. Abdool-Karim, 1992. Teenagers seeking condoms at family planning services. Part 1. A user's perspective. South African Med. J., 82: 356-359.

7. Abdool-Karim, S. S., Q. Abdool-Karim, E. Preston-Whyte and N. Sankar, 1992. Reasons for lack of condom use among high school students. South African Med. J., 82: 107-110.

8. Soul City, 2001. Soul City life skills Grade 9 workbook. Johannesburg: Author.

9. Carey, M.P., and K.E. Schroder, 2002. Development and psychometric evaluation of the brief HIV Knowledge Questionnaire. AIDS Education and Prevention, 14: 172-182.

10. Basen-Engquist, K., L.C. Masse, K. Coyle, D. Kirby, G.S. Parcel, S. Banspach and J. Nodora, 1999. Validity of scales measuring the psychosocial determinants of HIV/STD-related risk behaviour in adolescents. Health Edu. Res., 14: 25-38.

11. Pattullo, A.L.S., M. Malonza, G.G. Kimani, A. Muthee, P.A.O. Otieno, K. Odhiambo, S. Moses and F.A. Plummer, 1994. Survey of knowledge, behaviour and attitudes relating to HIV infection and AIDS among Kenyan secondary school students. AIDS Care, 6: 173-181.

12. Kaiser Family Foundation, 2000. South African national youth survey. Johannesburg: Love Life.

13. Van Dyk, A.C., 2001. Traditional African beliefs and customs: implications for AIDS education and prevention in Africa. South African J. Psychol., 31: 60-66.

14. Peltzer, K., 1995. Psychology and health in Africa. Frankfurt/M.: IKO Verlag.

15. Eaton, L., A.J. Flisher and L.E. Aarø, 2003. Unsafe sexual behavior in South African youth. Social Sci. Med., 56: 149-165.

16. Kelly, K., 2000. Communicating for action: a contextual evaluation of youth responses to HIV/AIDS. Grahamstown: CADRE.

17. Hartung, T.K., J. Nash, N. Ngubane and V.G. Fredlund, 2002. AIDS awareness and sexual behavior in a high HIV prevalence area in rural northern KwaZulu-Natal, South Africa. Int. J. STD and AIDS, 13: 829-832. 